\title{
Morphological Variations, Patterns of Frontal Ambulacrum Pores and Paleoecology of Heteraster renngarteni Poretzkaja (Echinoidea: Spatangoida) from Aptian Sediments of Baghin Area, Kerman, Iran
}

\author{
Mohammed Raza Vaziri* and Ahmad Lotfabad Arab \\ Geology Department, Faculty of Sciences, Shahid Bahonar University, Kerman, Islamic Republic of Iran
}

(received July 30, 2009; revised July 25, 2010; accepted August 30, 2010)

\begin{abstract}
Detailed macro- and microscopic analysis of spatangoid echinoid, Heteraster renngarteni Poretzkaja showed a remarkable variation in morphology and alternation of short and long pores in the frontal ambulacrum. The differentiation of pores in the frontal ambulacrum has been interpreted as an adaptive strategy for survival in a shallow shelf environment whereas, variation in morphology appears to be influenced mainly by grain size of the substrate.
\end{abstract}

Keywords: echinoids, Iran, ambulacrum pores, Heteraster renngarteni, Cretaceous, Kerman

\section{Introduction}

Phylogenetic schemes for spatangoid relationships have been proposed by Smith (1984) and more recently by Neumann (1999). The order Spatangoida appeared first in the lowermost Cretaceous (Berriasian). Within the spatangoids, the family Toxasteridae originated probably from a disasteroid ancestor. During the Berriasian to the Aptian, diversification of the family led to appearance of three genera (Toxaster, Aphelaster, and Heteraster). These genera were a rootstock for all the later Spatangoida (Villier et al., 2004).

The genus Heteraster appeared first during the Hauterivian. From this time to the Barremian, diversity of the genus is very low (fewer than 5 species). The acme of diversity occurs in the Aptian and Albian with about 20 species (Villier et al., 2001). Afterward, diversity decreases again and finally the genus disappears during the Early Cenomanian. The genus Heteraster is unique among spatangoids, because its frontal ambulacrum consists of an alternation of short and long pores. The patterns of pore distribution in Heteraster were documented by Devries (1955) and Villier et al. (2001).

Cotteau (1890) proposed the name Heteraster as a synonym of Enallaster. Adkins (1928) Lambert and Thiery (1924) and Lambert (1920), regarded Enallaster as a junior synonym of Heteraster, while Cooke (1946) considered Enallaster at least as a subgenus of Heteraster. Although the genus Heteraster comprises of 34 species

*Author for correspondence; E-mail: vazirimohammadreza @yahoo.com of spatangoids (Villier et al., 2001), there is no revised monograph of the genus. Description of Iranian material will improve knowledge about the genus and help compare it with the specimens reported from the other parts of the world.

$H$. renngarteni, on which this study focused, is a rather large toxasterid echinoid and occurs abundantly in Aptian marls of Baghin area, west of Kerman, Iran. Apparently, this primitive spatangoid is a highly endemic taxon, described previously from Azerbaijan (Ali-zadeh, 1988) and Turkmenistan (Lobacheva, 1968) but is reported for the first time from Iran herein.

Geological setting and stratigraphy. The species Heteraster renngarteni, described here, was collected from Aptian strata that crop out in Baghin area, west of Kerman city (Fig. 1). The Aptian sediments of Baghin consists mainly of alternation of green marls and thin layers of yellow shaly limestone (Fig. 2) with an abundant benthic fauna of Orbitolina, brachiopods, oysters, bivalves, gastropods and corals. Echinoids are also among the most conspicuous and diverse constituents of the Aptian fauna of Baghin area, represented by Stomechinidae, Emiratidae, Pygaulidae, Holectypidae, Cidaroida, Stirodonta, Hemiasteridae, Toxasteridae and Acropeltidae, among which the last two are the dominant groups of the assemblage. The Aptian marls are covered by a gray, bioturbated and thick-bedded limestone, relatively barren of macro-invertebrates. 


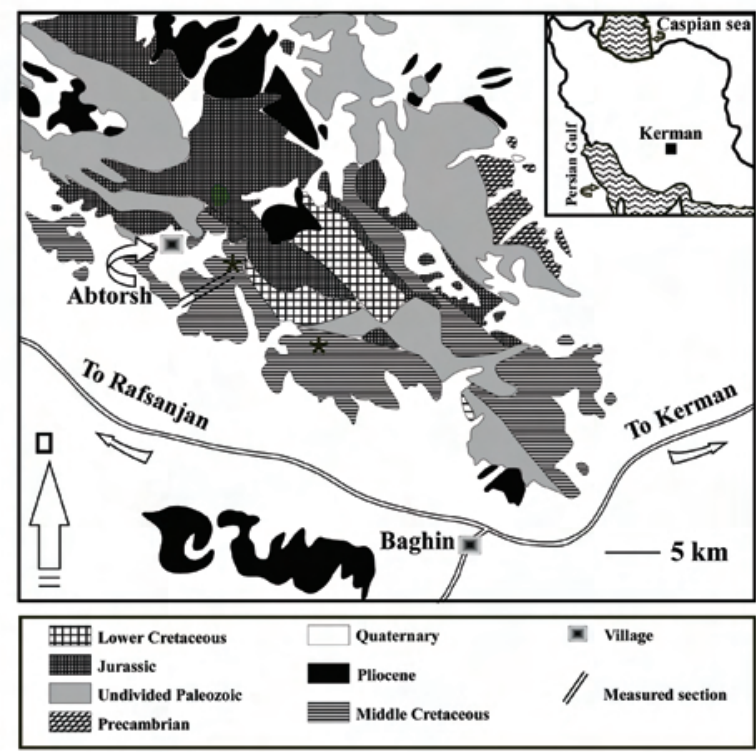

Fig. 1. Simplified geological map of the Baghin area. Black stars show the localities from where $H$. renngarteni was collected.

\section{Materials and Methods}

For studying the $H$. renngarteni, 325 specimens of this toxasterid spatangoid were collected from green marls of Baghin area (Figs. 3 and 4). About two third of the specimens were crushed, distorted, imperfect, or weathered. Well preserved specimens were cleaned, using a mild detergent and whenever necessary by using an ultrasonic vibrator and a preparation needle. In order to study pore arrangement, a light binocular microscope was used and pore distribution was considered only from the medial part of the frontal ambulacrum.

The materials used in this study are housed in the Paleontology Laboratory of Shahid Bahonar University of Kerman, Iran.

\section{Systematic paleontology}

Phylum: Echinodermata Leske, 1778

Class: Echinoidea Leske, 1778

Cohort: Irregularia Latreille, 1825

Order: Spatangoida Claus, 1876

Family: Toxasteridae Lambert, 1920

Genus: Heteraster d'Orbigny, 1853

Species: Heteraster renngarteni Poretzkaja, 1961

Diagnosis. The specimens were relatively large, moderately inflated, truncate behind, highest point slightly behind the center. As other Spatangoida, the plastron is of an amphisternous type, characterized by a labrum con-

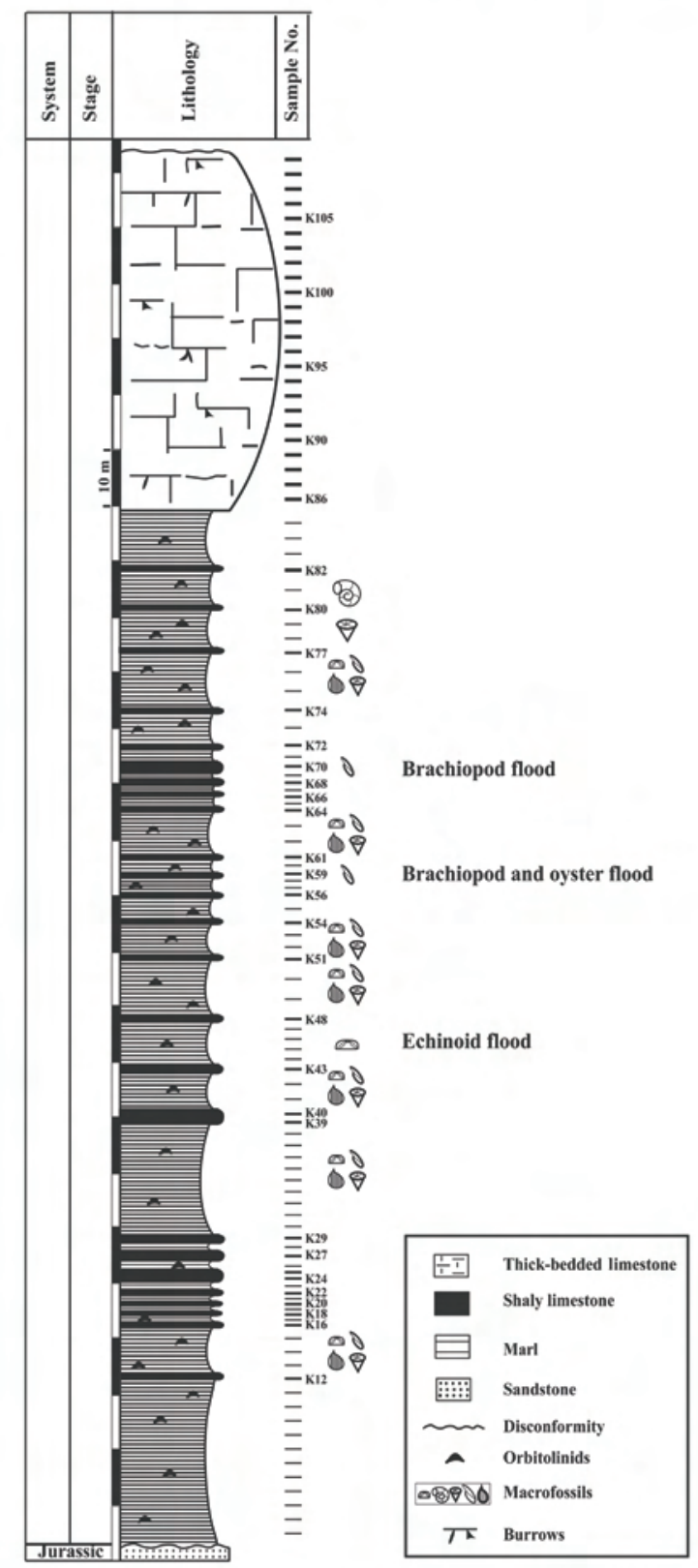

Fig. 2. Schematic lithological succession of Aptian strata in Baghin area.

nected at its posterior end to two large, equally developed sternal plates (Fig. 3c). Apical disc lies approximately centrally, varying with the shape of the test. It is ethmophract with the madreporite not very much larger than the other genital plates. Genital plates 1 and 4 have usually a broad zone of contact. All the genital plates are perforated by a rounded gonopore. In one specimen, where the madreporite is remarkably minute, the genital plates are not in contact with each other (Fig. 3d, e). Since this specimen seems identical with the several other examples examined in all other respects, we regard it as an 


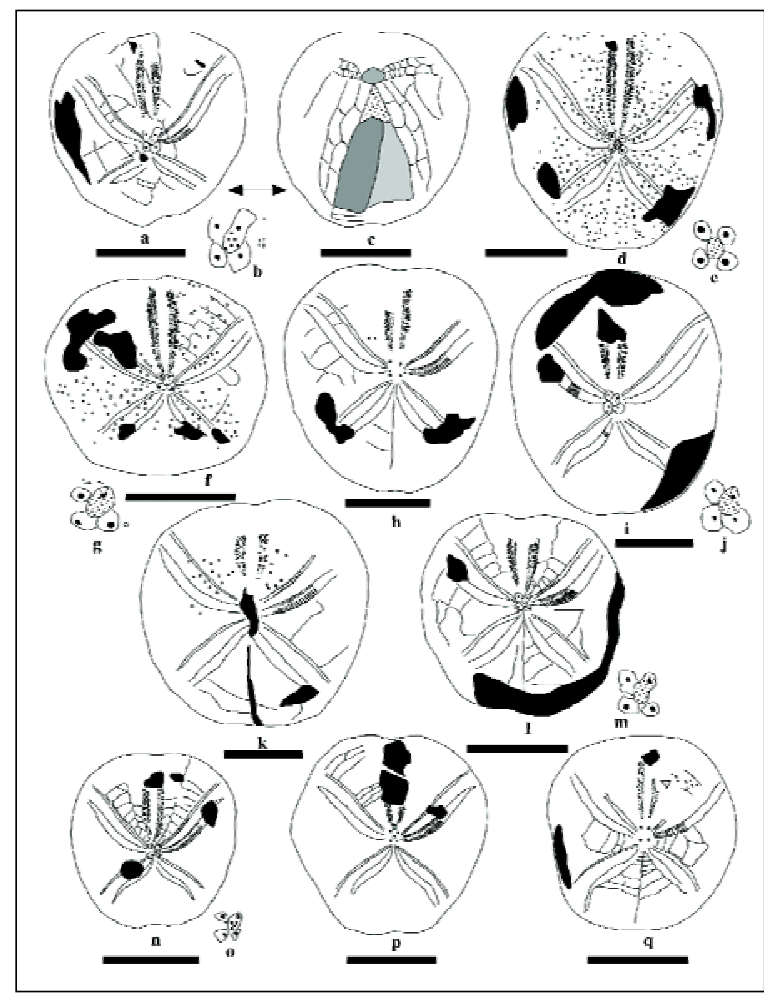

Fig.3. Camera lucida drawings of apical: (a, d, f, h, i, k, l, n, p, q), oral: (c) and apical disc (b,e,g,j,m,o) views in different specimens of H. renngarteni Poretzkaja, from the Aptian of Baghin area. Scale bars represent $1 \mathrm{~cm}$.

abnormal development and not as a distinct variety. Frontal sulcus was deep and well developed. Paired petals were broad and unequal in length. The anterior petals reached the ambitus, slightly curved backward, opened distally. Posterior petals were about $80 \%$ of the length of the anteriors ones and straighter (Figs. 3 and 4). Anterior ambulacrum was as wide as petals, sunken from apex to peristome. Interambulacral areas were about twice as wide as the ambulacral areas. No fasciole was present. Periproct was relatively large and situated longitudinally towards top of posterior truncate face (Fig.4c). Oral surface was flat, peristome relatively large, pentagonal in outline, one-fourth the length from the front (Fig. 4b). In some specimens, tuberculation was highly dense (Fig. 3d).

Morphology and arrangement of pore pairs in the frontal ambulacrum. The specimens of $H$. renngarteni found in the Baghin area showed considerable variation in morphology and also pore arrangement in the frontal ambulacrum. The specimen outline can be cordiform, ovate, circular, subquadrate or even hexagonal (Figs. 3 and 4), but usually cordiform.

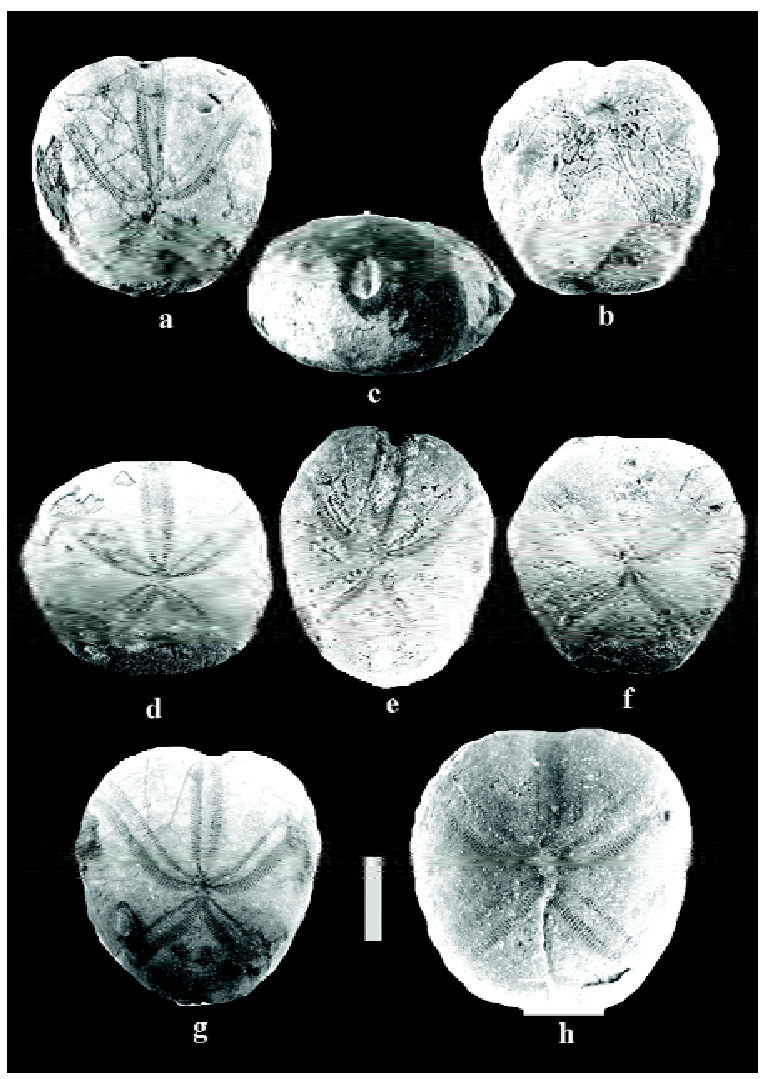

Fig. 4. Heteraster renngarteni Poretzkaja; a-c: (SBM 22011): apical, oral and posterior views; d: (SBM 22013); e: (SBM 22018); f: (SBM 22012); g: (SBM 22022) and h: (SBM 22031) apical views. All from the Aptian marls of Baghin area. Scale bar represents $1 \mathrm{~cm}$.

The alternation pattern of short and long pores in the frontal ambulacrum was also variable (Fig. 5). In the apical part of the ambulacrum, all the specimens exhibited an identical pore pattern. In this part all the pores were small and showed same size, while along the medial part, differentiation began and arrangement was quite irregular with one short isopore alternating with one, two, three or four elongate anisopores, but usually one short to two or three long.

\section{Results and Discussion}

$H$. renngarteni specimens found in Baghin area differed from $H$. oblongus and $H$. peroni in having a nearly central position of the apical disc and less flexuous petals. It is closest to the H. couloni (from Western Europe) and $H$. heckeri (from Azerbaijan). It can be differentiated from $H$. couloni by the structure of ambulacrum III and the relative width of the petals. Some specimens were very similar to $H$. heckeri Melikov, 1989 as the 


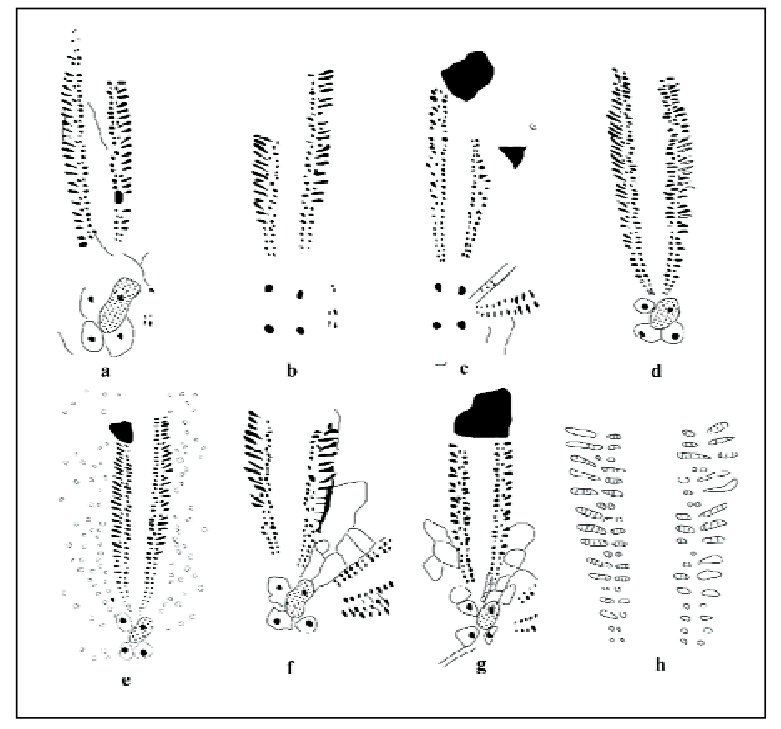

Fig. 5. Heterogeneity of pores in the frontal ambulacrum and architectural types of the apical disc in some specimens of $H$. renngarteni Poretzkaja, from the Aptian of Baghin area; $\times 2.5$ (appro.).

pores showed a sieve-like feature (Fig. 5h). It seems that $H$. renngarteni is synonymous with $H$. heckeri.

Ecological interpretation. Echinoid requirement for oxygen depends on many factors including: size, deve-lopmental stage, temperature and animal activities (Farmantarmanian, 1966). In warm waters of shallow environment the metabolic rate is high, while gas exchange decreases. Therefore, echinoids dwelling in shallow warm waters have more trouble in obtaining oxygen.

The relation between functional anatomy of tube feet and morphology of the related pores has been described by Nichols (1959) and Smith (1980, 1978). Long pores are related to respiratory function, while short ones are characteristic of tube feet since their main function is burrowing or food transport. In $H$. renngarteni, the long pores are frequent and show about $70 \%$ of the alternation of the frontal ambulacrum (Table 1).

This percentage is similar to that of $H$. ucetiae, which inhabits shallow environment (Villier et al., 2001). This fact suggests that the high percentage of long pores in $H$. renngarteni can be considered as an adaptive strategy for living in shallow environment, because, as stated above, in shallow- water species, the rate of respiration increases and demand for oxygen is high, so respiratory tube feet are frequent (Table 1).
Table 1. Alternation of two types of pores in the frontal ambulacrum, from apex to ambitus in seven specimens of $H$. renngarteni

\begin{tabular}{llll}
\hline \hline $\begin{array}{l}\text { Sample } \\
\text { no. }\end{array}$ & $\begin{array}{l}\text { Total number } \\
\text { of pores }\end{array}$ & $\begin{array}{l}\text { Number of } \\
\text { elongated pores }\end{array}$ & $\begin{array}{l}\text { Elongated } \\
\text { pores (\%) }\end{array}$ \\
\hline 1201 & 35 & 25 & 71.4 \\
1202 & 33 & 23 & 69.6 \\
1203 & 32 & 22 & 68.7 \\
1204 & 47 & 34 & 72.3 \\
1205 & 42 & 30 & 71.4 \\
1206 & 25 & 17 & 68 \\
1207 & 27 & 19 & 70.3 \\
\hline \hline
\end{tabular}

The warm environment is also confirmed by conspicuous presence of reef corals (shallow water corals) among faunal assemblage of Baghin area and indicates that the Aptian marls were deposited where the water depth was shallower than $50 \mathrm{~m}$ and temperature, warmer than $26^{\circ} \mathrm{C}$ (Tsaparas and Diacantoni, 2005).

Detailed macroscopic analysis also shows that there is wide morphological variation in the test shape of $H$. renngarteni. Spatangoid irregular sea urchins are detritivorous benthic organisms (Saucède et al., 2006), and almost all of them live buried in sandy to muddy sediment from superficial layers to more than $20 \mathrm{~cm}$ deep. This mode of life enables the spatangoids to gain access to new food resources and escape from predators (Smith, 1984). Variation in test shape of echinoids appears to berelated to sediment granulometry, to the depth of burrowing, and to water depth (Saucède, et al., 2007; Kanazawa, 1992; Néraudeau and Moreau, 1989; Zaghbib-Turki, 1989; Nichols, 1959; Smith and Paul, 1985). This study shows that there is no marked diffe-rence in percentage of respiratory tube feet among different specimens of $H$. renngarteni (Table 1). Those tube feet represent about $70 \%$ of the pores in frontal ambulacrum in nearly all the studied samples. This observation suggests that considerable variation in the test outline of Heteraster renngarteni, collected from Baghin area, is not dependent upon spatial distribution (i.e. occupation of different levels within the sediments to minimize competition between species or water depth), but may results from granulometric parameters. In other words, although $H$. renngarteni population was located in marly facies, this highly sensitive community was more influenced by the grain size than the other factors (Fig. 6). Closely spaced tubercles in some specimens, that supported a dense cover of spines, might be a device for stabilization of the walls of burrows in more loose sediments. 


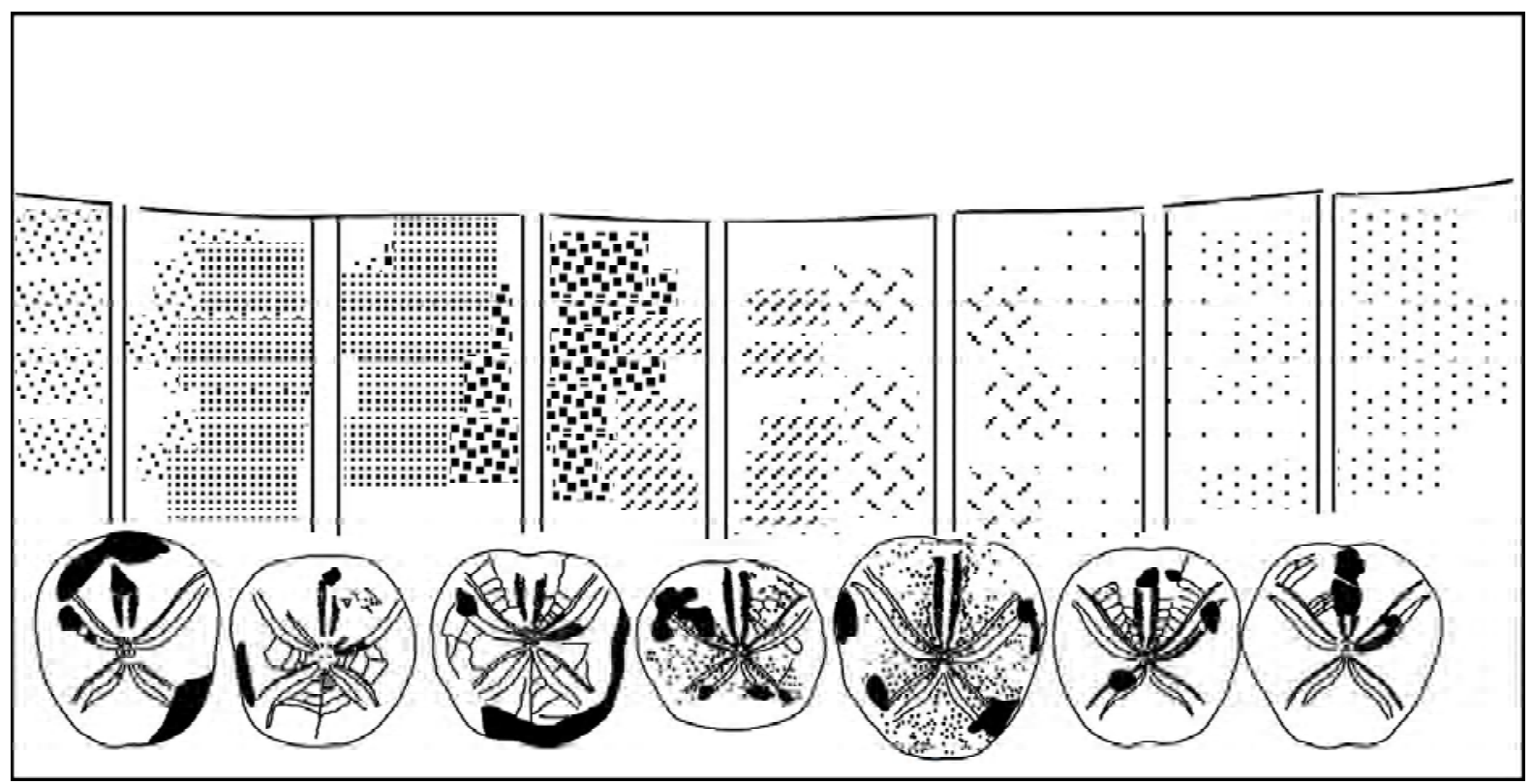

Fig. 6. Schematic diagram of the habitat of the different specimens of $H$. renngarteni from the Aptian marls of Baghin area. Grain symbols do not imply to any particular grain size, but just show that the difference in the test shape is significantly influenced by granulometry of the sediments.

\section{Acknowledgement}

The authors are deeply indebted to professor Loïc Villier, Université de Provence, France for his guidance and constructive discussion during the course of study. Special thanks to individuals who helped to collect Heteraster renngarteni from Baghin area, including J. Hasani, M. Derisi, S. Jaber and M. Rami.

\section{References}

Adkins, W.S. 1928. Handbook of Texas Cretaceous Fossils, University of Texas Bulletin (Austin), 2838: 1-385.

Ali-zadeh, Ak.A. 1988. Cretaceous fauna of Azerbaijan. Baku. Elm., 648 pp., (in Russian) available on http://www.jurassic.ru/cretaceous.eng.htm.

Cooke, C.W. 1946. Comanche Echinoids. Journal of Paleontology, 20: 193-237.

Cotteau, G. 1890. Echinides nouveaux ou peu connus. $9^{\text {th }}$ part. Memoires Societe Zoologique de France, 3: 537-550.

Devries, A. 1955. Note sur le ge nre Heteraster. Bulletin de la Société Géologique de France, 6: 315-323.

Farmantarmaian, A. 1966. The respiratory physiology of echinoderms. In: Physiology of Echinodermata, R. A. Boolootian (ed.), pp. 245-266, Wiley Interscience, New York, USA.

Kanazawa, K. 1992. Adaptation of test shape for burrowing and locomotion in spatangoid echinoids. Palaeontology, 35: 733-750.

Lambert, J. 1920. Sur quelques genres nouveaux d échinides. Memoires de la Societe Academique d'Agriculture des Sciences, Arts et Belleslettres du Département de Aube; Serie 3, 55: 145-174.

Lambert, J., Thiery, P. 1924. Essai de Nomenclature Raisonnée des Echinides.Chaumont, Ferrière, Fasc. 6 and 7, 1909-1925.

Lobacheva, S.B. 1968. On the early cretaceous sea urchins of genus Epiaster, Turkmenistan. Annual Review of the Soviet Paleontological Society, 18: 268-281 (in Russian).

Néraudeau, D., Moreau, P. 1989. Paléoécologie et paléobio-géographie des faunes d'échinides du Cénomanien nord-aquitain (Charente-Maritime, France). Geobios, 22: 293-324.

Neumann, C. 1999. New spatangoid echinoids (Echinodermata) from the Upper Cretaceous of Jordan: their taxonomy and phylogenetic importance. Berliner Geowissenschaftliche Abhandlung, E, 30: $175-189$.

Nichols, D. 1959. Mode of life and taxonomy in irregular sea-urchins. Systematics Association Publication, 3: 61-80.

Saucède, T., Mooi, R., David, B. 2007. Phylogeny and origin of Jurassic irregular echinoids (Echinodermata: Echinoidea). Geological Magazine, 144: 333-359. 
Saucède, T., Alibert, P., Laurin, B., David, B. 2006. Environmental and ontogenetic constraints on developmental stability in the spatangoid sea urchin Echinocardium (Echinoidea). Biological Journal of the Linnean Society, 88: 165-177.

Smith, A.B., Paul, C.R.C. 1985. Variation in the irregular echinoid Discoides during the Early Cenomanian. Special Papers in Palaeontology, 33: 29-37.

Smith, A.B. 1984. Echinoid Palaeobiology, 190 pp., Allen and Unwin, London, UK.

Smith, A.B. 1980. The structure, function, and evolution of tube feet and ambulacral pores in irregular echinoids. Palaeontology, 23: 39-83.

Smith, A.B. 1978. A functional classification of the coronal pores of regular echinoids. Palaeontology, 21: 759-789.

Tsaparas, N., Marcopoulou-Diacantoni, A. 2005.
Tortonian Scleractinian corals from the island of Gavdos (South Greece). Revue de Paléobiologie, 24: 629-637.

Villier, L., Neraudeau, D., Clavel, B., Neumann, C., David, B. 2004. Phylogeny of early Cretaceous spatangoids (Echinodermata: Echinoidea) and taxonomic implications. Palaeontology, 47: 265-292.

Villier, L., David, B., Neraudeau, D. 2001. Ontogenetic and morphological evolution of the ambulacral pores in Heteraster (early spatangoids). In: Echinoderm 2000, M Barker (ed.), pp. 563-567, Balkema, Rotterdam, The Netherlands.

Zaghbib-Turki, D. 1989. Les Échinides indicateurs des paléoenvironments: un exemple dans le Cénomanien de Tunisie. Annales de Paléontologie (Invertébrés), 75: 63-81. 